\title{
Perancangan Sistem Monitoring Penjualan Untuk Optimalisasi Penjualan Sayuran Pada Kelompok Tani Hidroponik Menggunakan Metode Single Exponential Smoothing (SES)
}

\author{
Novi Indrayani ${ }^{1}$, Nasruddin Bin Idris ${ }^{2}$ \\ Dosen Universitas Mulia ${ }^{1,2}$ \\ Jalan Let. Jend. TNI Z.A. Maulani No.9 Balikpapan \\ Sur-el : novi.indrayani.09@gmail.com ${ }^{1}$, bigmonsters88@gmail.com²
}

\begin{abstract}
One important aspect of buying and selling activities is the proper tabulation of sales data. During its development, many ways are used to store and process sales data, systems with varied features and different results according to user needs. In this study, researchers developed a system that can be accessed easily, web-based with a case study of selling hydroponic vegetables. This Sales Monitoring System can be used as a tool to record sales data, so that farmers are expected to use the data to predict the types of vegetables that should be planted. The forecasting process uses the Single Exponential Smoothing method using sales data as reference data. This system can also use to monitor the vegetables that are put into stalls or market places, and also see the accumulated monthly income. Apart from farmers, there are 3 other user categories in this system; admin, accountant and super admin.
\end{abstract}

Keywords: System, monitoring, predictions, sales, vegetables, SES

\begin{abstract}
Abstrak: Salah satu aspek yang penting dalam kegiatan jual beli adalah tabulasi data penjualan yang tepat. Dalam perkembangannya, banyak cara yang digunakan untuk menyimpan dan mengolah data penjualan, sistem dengan fitur yang sangat bervariasi dan hasil yang berbeda sesuai dengan kebutuhan penggunanya. Dalam penelitian ini, peneliti mengembangkan sistem monitoring penjualan yang dapat diakses dengan mudah karena berbasis web dengan studi kasus penjualan sayuran hidroponik. Sistem Monitoring Penjualan ini dapat digunakan sebagai alat untuk merekam data penjualan, sehingga para petani diharapkan dapat menggunakan hasil tabulasi datanya untuk keperluan memprediksi jenis sayuran yang harus ditanam. Proses peramalan menggunakan metode Single Exponential Smoothing dengan menggunakan data penjualan sebagai data acuan. Sistem ini juga dapat memudahkan petani untuk memonitor sayuran yang dimasukkan ke lapak atau marketplace, dapat pula melihat akumulasi penghasilan perbulan. Selain petani, ada 3 kategori pengguna lain dalam sistem ini yaitu admin, akuntan dan super admin.
\end{abstract}

Kata kunci: Sistem, monitoring, prediksi, penjualan, sayuran, SES

\section{PENDAHULUAN}

Pertumbuhan populasi yang semakin padat berdampak pada semakin sempitnya lahan pertanian, sehingga banyak sumber pangan kita yang terpaksa harus di impor dari luar negeri. Padahal jika dilihat lebih seksama sumberdaya dalam negeri mampu memenuhinya, apalagi ditunjang dengan teknologi yang semakin maju. Keterbatasan lahan pertanian ini, pada akhirnya mempengaruhi perubahan sistem pertanian, hal ini dapat dilihat dari semakin beragamnya sistem pertanian diantaranya adalah sistem pertanian hidroponik.

Istilah hidroponik digunakan untuk menjelaskan tentang cara bercocok tanam tanpa menggunakan tanah sebagai media tanamnya [10], yang memanfaatkan lahan sempit di tengah perkotaan untuk bercocok tanam. Dewasa ini sistem pertanian hidroponik semakin diminati 
masyarakat perkotaan, di samping karena kemudahannya juga karena prakteknya yang tidak menggunakan pestisida, hal ini seiring dengan tren gaya hidup sehat di masyarakat. Serapan hasil pertaniannya yang tinggi, sehingga menjadi celah bisnis baru bagi usaha mikro kecil, banyak kelompok tani mulai bermunculan untuk memenuhi kebutuhan pasar akan hasil pertanian hidroponik. Namun yang menjadi kendala adalah lahan yang terbatas, sehingga diperlukan pengelolaan yang tepat agar dapat mengoptimalkan lahan untuk meningkatkan hasil panen.

Kendala yang dihadapi dalam usaha pertanian hidroponik adalah pengelolaan kebun untuk mengoptimalkan hasil panen yang berkelanjutan, mengingat keterbatasan lahan. Seperti pada pertanian konvensional terkadang ada beberapa jenis sayuran yang penyerapan pasar nya tidak maksimal sedangkan varietas lain cenderung kekurangan, hal ini karena proses penentuan jenis sayuran yang ditanam masih belum tepat. Ditambah lagi permintaan pasar akan hasil pertanian hidroponik mensyaratkan harus dalam keadaan segar, artinya supply dilakukan setiap hari, jadi pengelolaan kebun harus didesain sedemikian rupa sehingga permintaan pasar setiap hari dapat dipenuhi. Pada usaha mikro kecil tentunya akan sangat terasa kerugiannya karena kelebihan hasil panen pastinya akan menurunkan harga jual, penurunan harga jual ini diambil sebagai langkah untuk mengurangi kerugian karena mengingat sayuran merupakan bahan makanan yang cepat rusak.

Kendala-kendala tersebut diatas, menjadi inspirasi untuk membuat sebuah sistem informasi atau aplikasi tertentu yang dapat digunakan untuk mengelola kebun-kebun yang dimiliki oleh kelompok tani pada usaha mikro kecil, serta aplikasi yang dapat menentukan jenis sayuran dan kuantiti penanaman.

Sistem informasi memberikan nilai tambah terhadap proses kualitas manajemen, pengambilan keputusan, dan pemecahan masalah serta keunggulan kompetitif yang berguna bagi kegiatan pelayanan [1]. Metode SES merupakan metode prediksi kuantitatif dengan pola data yang tidak stabil dan berdasarkan deret waktu [3].

Karakteristik dari metode ini adalah menggunakan parameter yang berbeda untuk data masa lalu, dimana parameternya menurun secara eksponensial mulai dari nilai pengamatan yang paling baru sampai dengan nilai pengamatan yang paling lama [8]. Hasil dari pemrosesan data penjualan ini diharapkan dapat meminimalkan resiko hasil panen jenis sayuran tertentu tidak secara optimal terserap pasar dan lain daripada itu lahan pertanian yang sempit pun dapat memberikan hasil yang optimal bagi para petani.

\section{METODOLOGI PENELITIAN}

Subjek dalam penelitian ini adalah Sistem Monitoring Penjualan, sebuah sistem untuk memonitoring penjualan sayuran. Sedangkan objek dalam penelitian ini adalah penerapan metode SES yang digunakan untuk memproses data hasil penjualan untuk keperluan prediksi penjualan selanjutnya yang terkait langsung dengan optimalisasi penyerapan hasil panen. 


\subsection{Pengumpulan Data}

Pengumpulan data yang digunakan dalam penelitian ini adalah sebagai berikut :

a. Observasi

Proses observasi didasarkan pada pengamatan langsung dan mencatat perilaku atau kejadian seperti keadaan yang sebenarnya. Pengumpulan data secara observasi dilakukan dengan pengamatan atau melihat langsung proses dan kegiatan yang berjalan, yang dilakukan sejak bulan April 2019 untuk memperoleh dan mengumpulkan data-data yang berhubungan.

b. Studi Literatur

Penelusuran literatur yang ada serta mendapatkan informasi atau data dari berbagai sumber bacaan jurnal atau hasil penelitian terdahulu yang berkaitan dengan judul atau topik pembahasan dari penelitian. Selain itu juga penulis mencari data atau informasi dari situssitus internet yang berkaitan dengan judul atau topik pembahasan dari penelitian.

\subsection{Agile Development}

Penelitian akan dilaksanakan melalui beberapa tahapan yang diadopsi dari siklus pengembangan perangkat lunak yaitu, Agile Development yang memiliki beberapa tahapan seperti yang ditunjukkan pada gambar 1 [7]:

1. Perencanaan, Tahap perencanaan meliputi analisa kebutuhan sistem dan user baik fungsional maupun non-fungsional.

2. Perancangan, Daftar kebutuhan fungsional yang diharapkan user tersebut lalu direpresentasikan dalam bentuk use case diagram
3. Pengembangan, Proses pengembangan dan kodefikasi berdasarkan diagram yang telah dibuat pada tahap perancangan.

4. Pengujian, Uji coba dilakukan pada seluruh kebutuhan fungsional yang tergambar pada use case diagram dan juga fitur-fitur tambahan yang terdaftar dalam kebutuhan non fungsional.

5. Pelepasan, Pelepasan sistem dilakukan dengan melakukan hosting di internet sehingga para petani dan user lain yang terlibat dapat menggunakan sesuai dengan perannya masing-masing.

6. Umpan Balik, Umpan balik diterima dari hasil pengalaman penggunaan sistem oleh para user pada tahap sebelumnya.

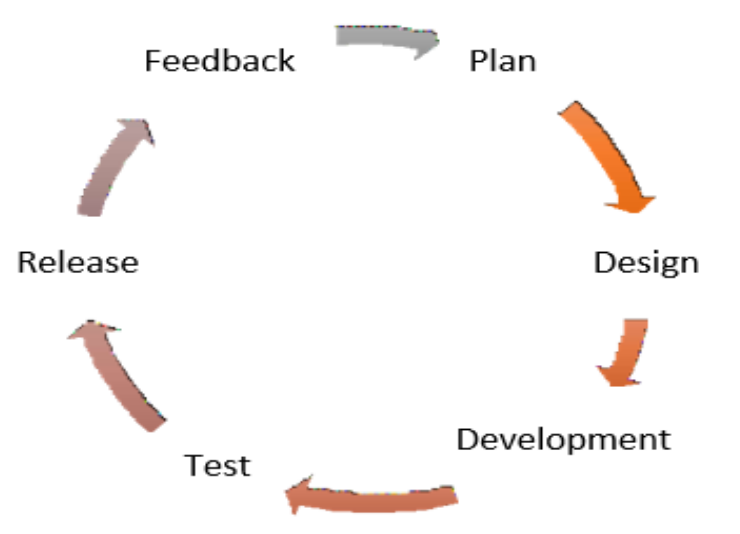

\section{Gambar 1. Siklus Pengembangan Agile}

\subsection{Framework CodeIgniter}

Framework dapat disimpulkan sebagai kumpulan instruksi dan fungsi. CodeIgniter merupakan salah satu framework php yang tidak berbayar. CodeIgniter menggunakan metode MVC (Model, View, Controller) [6].

- Model, Model merupakan bagian dari framework CodeIgniter yang melakukan pengolahan atau manipulasi database. 
- View, View merupakan bagian dari framework CodeIgniter yang menangani antarmuka sistem, atau halaman yang muncul di layar pengguna

- Controller, Controller merupakan bagian dari framework CodeIgniter yang menghubungkan antara Model dan View. Contoh; pengguna memberikan instruksi pada sistem melalui antarmuka, kemudian controller meneruskan instruksi tersebut ke model, lalu model memberikan data sesuai instruksi, lalu controller meneruskan data tersebut ke view, sehingga pengguna dapat melihat data yg diminta.

\subsection{Single Exponential Smoothing (SES)}

Metode single exponential smoothing atau penghalusan eksponensial tunggal adalah suatu prosedur yang secara terus menerus memperbaiki peramalan dengan merata-rata atau menghaluskan nilai masa lalu dari suatu data runtut waktu dengan cara menurun (eksponensial)[4]. Setiap data diberi bobot, dimana bobot yang digunakan disimbolkan dengan $\alpha$. Simbol $\alpha$ bisa ditentukan secara bebas, yang mengurangi forecast error [4].

Karakteristik dari metode ini yaitu :

1. Data yang dianalisis bersifat deret waktu.

2. Sesuai untuk data berpola horizontal.

3. Menggunakan bobot yang berbeda untuk data masa lalu, dimana bobotnya menurun secara eksponensial dari nilai pengamatan yang paling baru sampai nilai pengamatan yang paling lama.
Kelebihan metode ini adalah : [2]

1. Sudah mempertimbangkan pengaruh acak, trend dan musiman pada data masa lalu yang akan di proses.

2. Metode ini merupakan dasar bagi metode-metode pemulusan eksponensial lainnya.

3. Dapat digunakan untuk meramal data beberapa periode ke depan.

Kekurangan dari metode ini yaitu :[2]

1. Tingkat akurasi yang dihasilkan oleh metode ini masih terlalu rendah.

2. Metode pemulusan eksponensial tunggal tidak cukup baik diterapkan jika datanya bersifat tidak stasioner, karena persamaan yang digunakan dalam metode eksponensial tunggal tidak terdapat prosedur pemulusan pengaruh tren yang mengakibatkan data tidak stasioner menjadi tetap tidak stasioner.

Rumus yang digunakan pada single exponential smoothing adalah : [8]

$F_{t+1}=\alpha y_{t}+(1-\alpha) F_{t}$

Nilai peramalan untuk periode

$F_{t+1}=$ Nilai peramalan untuk periode $t+1$

$y_{t}=$ Data sebenarnya pada periode $t$

$F_{t}=$ Nilai ramalan periode $t$

$\alpha=$ Konstanta penghalusan $(0<\alpha<1)$

\section{HASIL DAN PEMBAHASAN}

Hasil pengumpulan data dan identifikasi kebutuhan baik kebutuhan pengembangan sistem, pengoperasian sistem dan kebutuhan 
pengguna (user) dapat disimpulkan sebagai berikut;

Kebutuhan pengembangan sistem :

- SQL Server

- Xampp Server Engine

- Framework Codeigniter

Kebutuhan fungsional :

- Mengelola otoritas login atau password, yaitu data password yang dimasukkan oleh admin dan petani dengan benar, dan selanjutnya memilih menu untuk melakukan aktivitas pekerjaan,

- Mengelola input, edit, update, delete untuk admin, petani, dan akuntan

- Mengolah sayur yang masuk ke kios melalui inputan dari petani, mengelola updatean stok sayur yang tersisa dari penjualan oleh admin

- Mengelola sistem untuk menyediakan laporan, seperti laporan stok sayur yang masuk, laporan stok sayur yang laku di hari pertama dan kedua, laporan sayur yang diretur dan laporan total penghasilan tiap bulannya.

Kebutuhan non-fungsional :

- Fitur login dan logout

- Notifikasi pada setiap jenis pengguna mengenai aktivitasnya dalam sistem

- Laporan penjualan

- Penggunaan barcode untuk proses penjualan

Kategori pengguna sistem :

- Petani

- Akuntan

- Admin
Adapun pemetaan kebutuhan baik fungsional maupun non-fungsional pada tiap kategori pengguna adalah sebagai berikut :

\subsection{Desain Diagram}

Visualisasi dari hasil identifikasi pengguna, kebutuhan fungsional dan non fungsional sistem monitoring penjualan, dituangkan dalam bentuk diagram-diagram yang merupakan bagian dari Unified Modelling Language (UML)[9]. UML adalah sebuah bahasa yang berdasarkan grafik atau gambar untuk memvisualisasi, menspesifikasikan, membangun, dan pendokumentasian dari sebuah sistem pengembangan software berbasis $\mathrm{OO}$ (Object-Oriented) [5].

Gambaran fungsional sistem dan interaksi pengguna dengan sistem dituangkan dalam use case diagram pada gambar 2 .

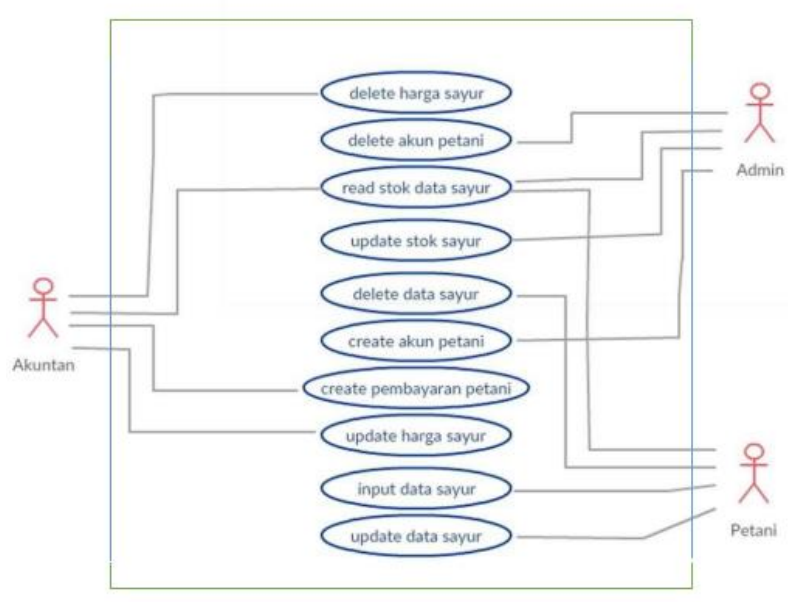

\section{Gambar 2. Use Case Diagram Sistem Monitoring Penjualan}

Workflow menggambarkan kondisi, kendala, aktivitas berurutan dan bersamaan, dimodelkan dengan activity diagram. Secara sederhana, Activity diagram menunjukkan 'How' sementara Use case menunjukkan 'What' untuk sistem tertentu [5]. 


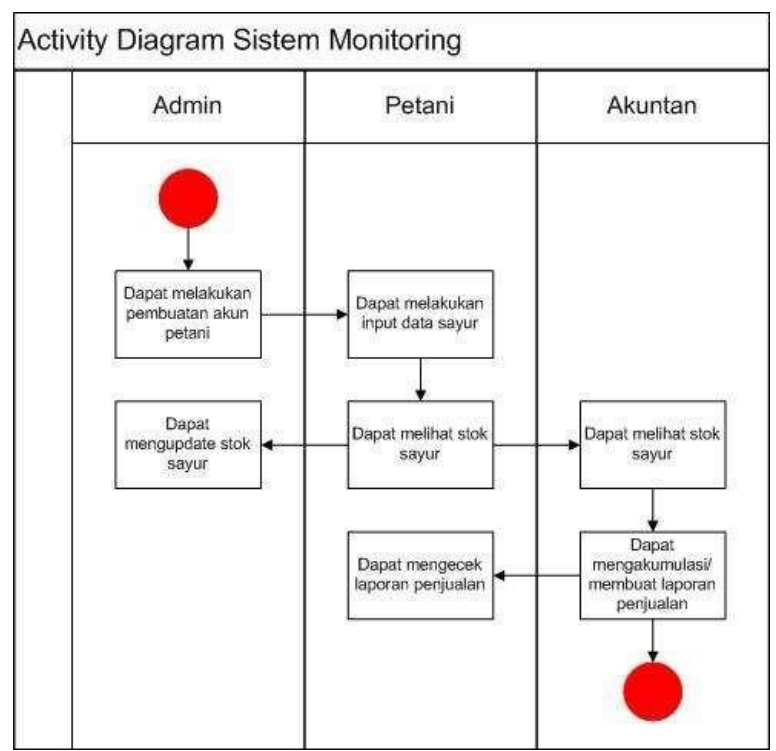

Gambar 3. Activity Diagram Sistem Monitoring Penjualan

Model data sistem, divisualisasikan dengan class diagram seperti pada gambar 4 .

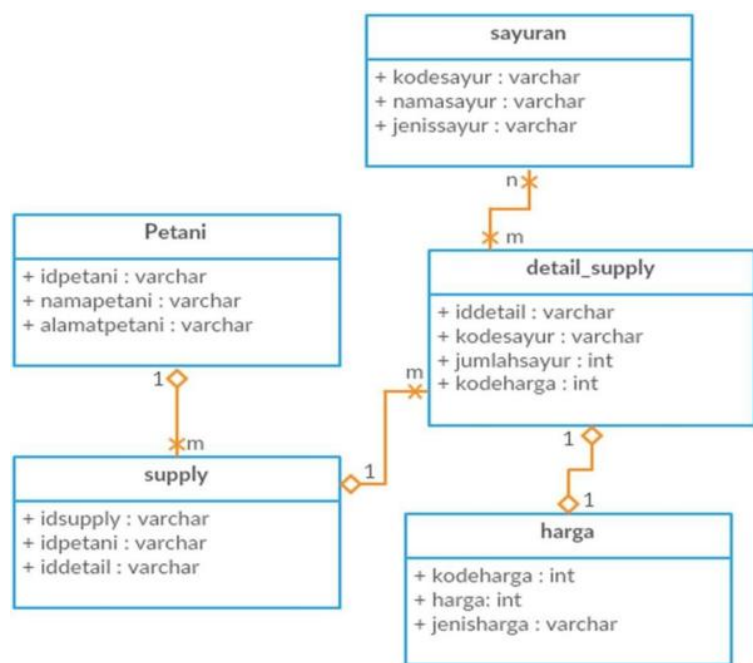

Gambar 4. Class Diagram Sistem Monitoring Penjualan

\subsection{Antarmuka Sistem}

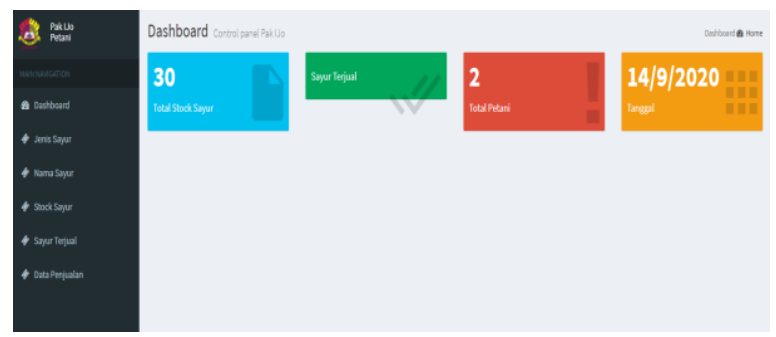

Gambar 5. Dashboard Sistem Monitoring Penjualan

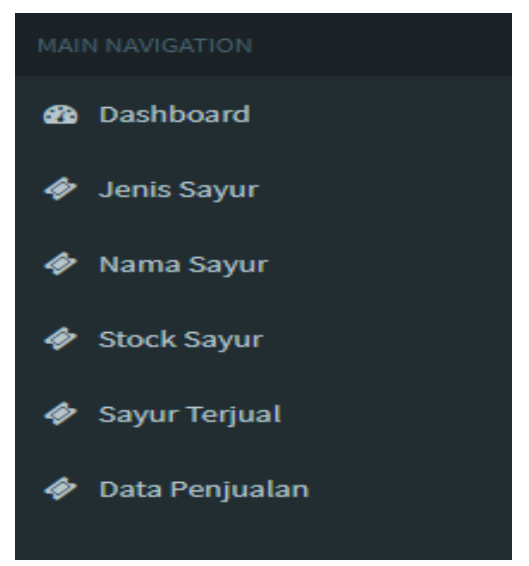

Gambar 6. Menu Navigasi

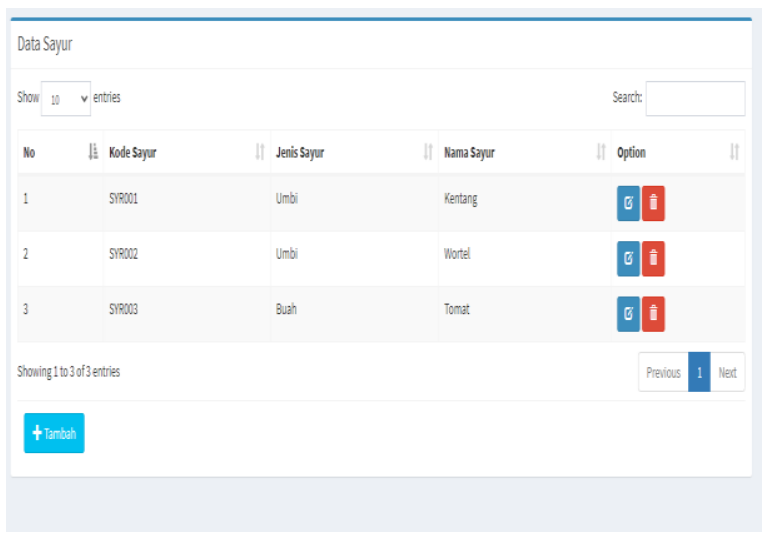

Gambar 7. Fitur Pengolahan Data Sayur

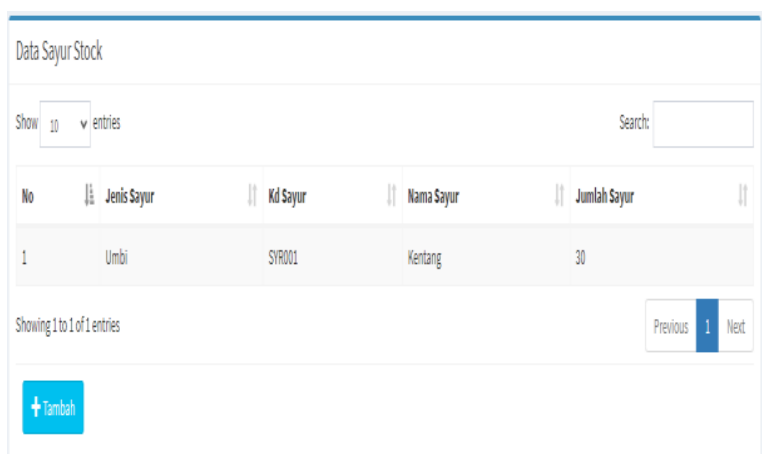

Gambar 8. Fitur Pengolahan Data Stok Sayuran

\subsection{Contoh Perhitungan SES dalam Sistem}

Data Penjualan beberapa jenis sayur dalam satu tahun terakhir akan digunakan untuk memprediksi penjualan di tahun berikutnya sehingga kuantiti penanaman bisa disesuaikan dengan hasil peramalan. 
Tabel 1. Contoh Hasil Peramalan menggunakan SES

\begin{tabular}{llcccc}
\hline \multirow{2}{*}{$\boldsymbol{N}$} & \multirow{2}{*}{ Bulan } & \multicolumn{2}{c}{ Selada } & \multicolumn{2}{c}{ Pakcoy } \\
\cline { 3 - 6 } & & $\boldsymbol{y}$ & $\boldsymbol{F}$ & $\boldsymbol{y}$ & $\boldsymbol{F}$ \\
\hline 1 & Januari & 350 & 350 & 90 & 90 \\
2 & Februari & 400 & 350 & 110 & 90 \\
3 & Maret & 500 & 360 & 80 & 94 \\
4 & April & 450 & 388 & 40 & 91,2 \\
5 & Mei & 550 & 400,4 & 90 & 80,96 \\
6 & Juni & 570 & 430,32 & 95 & 82,768 \\
7 & Juli & 400 & 458,256 & 80 & 85,2144 \\
8 & Agustus & 350 & 446,6048 & 80 & 84,17152 \\
9 & September & 200 & 427,28384 & 90 & 83,337216 \\
10 & Oktober & 300 & 381,827072 & 94 & 84,6697728 \\
11 & November & 450 & 365,4616576 & 100 & 86,53581824 \\
12 & Desember & 500 & 382,3693261 & 90 & 89,22865459 \\
\hline
\end{tabular}

Misalkan $\alpha=0,2$

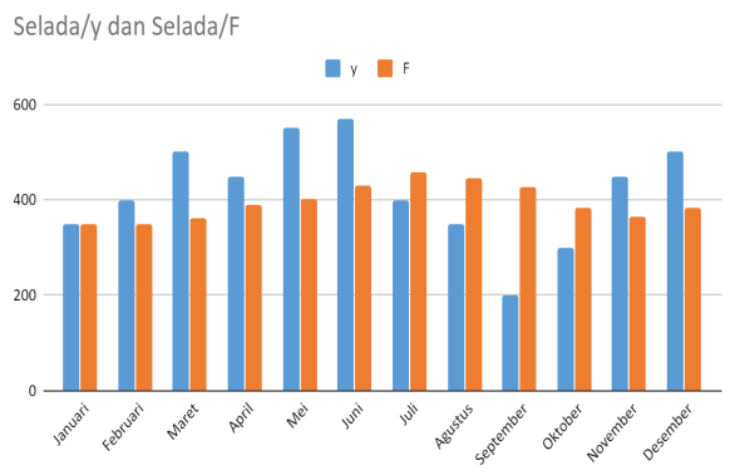

Bulan

\section{Gambar 9. Diagram perbandingan data penjualan dan hasil peramalan selada}

\section{Pakcoy/y, dan Pakcoy/F}

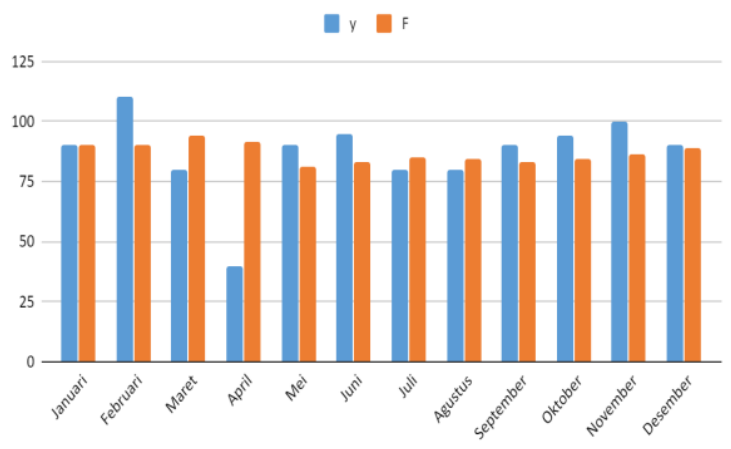

Bulan

Gambar 10. Diagram perbandingan data penjualan dan hasil peramalan pakcoy
Nilai konstanta dapat ditentukan dengan cara coba-coba. Namun dapat juga menggunakan Persamaan (2) [8]:

$$
\alpha=2 /(\mathrm{n}+1)
$$

Dimana :

$$
\begin{aligned}
& \mathrm{A}=\text { nilai Konstanta } \\
& \mathrm{n}=\text { jumlah periode waktu }
\end{aligned}
$$

Untuk contoh data pada tabel 1, jika menggunakan nilai konstanta 0,1 maka akan diperoleh hasil seperti pada tabel 2 .

Tabel 2. Peramalan dengan konstanta 0,1

\begin{tabular}{llcccc}
\hline \multirow{2}{*}{$\boldsymbol{N}$} & \multirow{2}{*}{ Bulan } & \multicolumn{2}{c}{ Selada } & \multicolumn{2}{c}{ Pakcoy } \\
\cline { 3 - 6 } $\boldsymbol{O}$ & & $\boldsymbol{y}$ & $\boldsymbol{F}$ & $\boldsymbol{y}$ & $\boldsymbol{F}$ \\
\hline 1 & Januari & 350 & 350 & 90 & 90 \\
2 & Februari & 400 & 350 & 110 & 90 \\
3 & Maret & 500 & 355 & 80 & 92 \\
4 & April & 450 & 369,500 & 40 & 90,800 \\
5 & Mei & 550 & 377,550 & 90 & 85,720 \\
6 & Juni & 570 & 394,795 & 95 & 86,148 \\
7 & Juli & 400 & 412,316 & 80 & 87,033 \\
8 & Agustus & 350 & 411,084 & 80 & 86,330 \\
9 & September & 200 & 404,976 & 90 & 85,697 \\
10 & Oktober & 300 & 384,478 & 94 & 86,127 \\
11 & November & 450 & 376,030 & 100 & 86,914 \\
12 & Desember & 500 & 383,427 & 90 & 88,223 \\
\hline
\end{tabular}

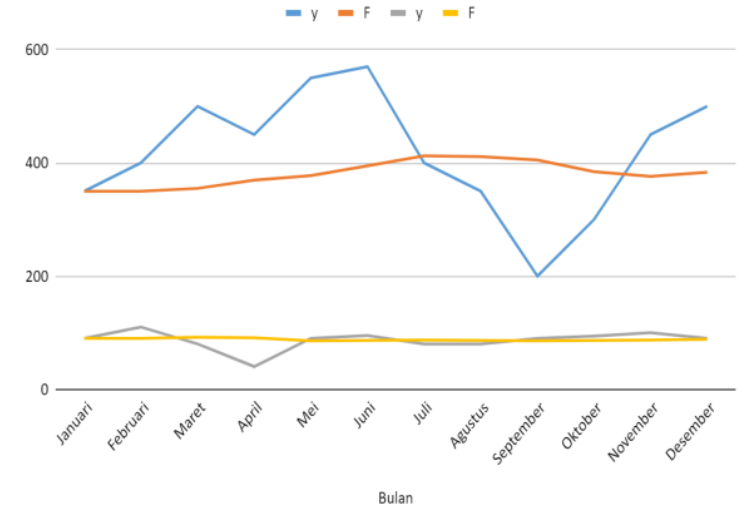

Gambar 11. Diagram peramalan dengan konstanta 0,1 


\section{KESIMPULAN}

\section{Penggunaan Single Exponential} Smoothing (SES) dalam penelitian ini sudah memberikan hasil yang baik, namun begitu belum optimal karena hasil peramalan tidak bisa mengikuti tren penjualan yang ada. Sehingga perlu dikembangkan lagi dengan metode peramalan yang lain. Penulis sempat melakukan perhitungan dengan metode eksponential yang lain yaitu Double Exponential Smoothing (DES), hasil peramalan bisa mengikuti tren penjualan, namun begitu tetap harus dikembangkan dengan metode yang memberikan hasil yang lebih optimal.

\section{UCAPAN TERIMA KASIH}

Direktorat Riset dan Pengabdian Masyarakat Direktorat Jenderal Penguatan Riset dan Pengembangan Kementerian Riset, Teknologi, dan Pendidikan Tinggi sesuai dengan Kontrak Penelitian Tahun Anggaran 2020.

\section{DAFTAR PUSTAKA}

[1] Saragi, A. B., Daulay, S. B. dan Harahap, L. A. 2018. Aplikasi Informasi Tanaman Perkebunan Kabupaten Deli Serdang Berbasis Android. J.Rekayasa Pangan dan Pertanian, Vol.6 No.1

[2] Anggi H. Djoni D. dan Wimmie H. 2012. Perbandingan Metode Single Exponential Smoothing dan Metode exponential Smoothing Adjusted for Trend (holt's method) untuk Meramalkan Penjualan. Studi kasus: toko onderdil mobil, Jurnal Eksis, Vol.5, No.1

[3] Handoko W. 2019. Prediksi Jumlah Penerimaan Mahasiswa Baru dengan Metode Single Exponential Smoothing (Studi Kasus AMIK Royal Kisaran),
JURTEKSI, Vol. V No. 2, Juni 2019, hlm. $125-132$

[4] Falani. I. 2018. Penentuan Nilai Parameter Metode Exponential Smoothing dengan Algoritma Genetik dalam Meningkatkan Akurasi Forecasting. CESS, Vol. 3 No. 1, pISSN :2502-7131, e-ISSN :2502-714x, pp. 14-16

[5] Suendri. 2018, Implementasi Diagram UML (Unified Modelling Language) Pada Perancangan Sistem Informasi Renumerasi Dosen Dengan Database Oracle (Studi Kasus: UIN Sumatera Utara Medan, Jurnal Ilmu Komputer dan Informatika: Vol.3 No.01, ISSN 2598-6341

[6] Destiningrum M, Adrian Q.J. 2017. Sistem Informasi Penjadwalan Dokter Berbasis Web dengan Menggunakan Framework Codeigniter (Studi Kasus: Rumah Saakit Yukum Medical Center), Jurnal Teknoinfo, Vol.11 NO.2, pp.30-37, ISSN 16930010

[7] Haryana, S.KM. 2019. Penerapan Agile Development Methods dengan Framework Scrum pada Perancangan Perangkat Lunak Kehadiran Rapat Umum Berbasis QR-Code, Jurnal Computech \& Bisnis, Vol.13 NO.2, pp.70-79, ISSN (print) 1978-9629 ISSN (online) 2442-4943

[8] A. C. Adamuthe, R. A. Gage, and G. T. Thampi. 2015. "Forecasting Cloud Computing using Double Exponential Smoothing Methods," International Conference on Advanced Computing and Communication Systems (ICACCS-2015), pp. 1-5.

[9] LARMAN, C., 2005. Applying UML and Patterns. 3rd Edition. NJ: Prentice Hall.

[10] Heriwibowo, K. dan Budiana, N.S. 2014. Hidroponik Sayuran Untuk Hobi dan Bisnis. Penebar Swadaya. Jakarta. 